\title{
SNARE complex at the ribbon synapses of cochlear hair cells: analysis of synaptic vesicle- and synaptic membrane-associated proteins
}

\author{
Saaid Safieddine and Robert J. Wenthold \\ Laboratory of Neurochemistry, National Institute on Deafness and Other Communication Disorders, NIH, Bethesda, MD 20892, \\ USA
}

Keywords: guinea-pig, rat, SNAP-25, synaptobrevin, synaptotagmin, syntaxin

\begin{abstract}
Neurotransmitters are released via exocytosis of synaptic vesicles involving a fusion complex consisting of a set of highly conserved proteins, which form a multiprotein complex resulting in the docking of synaptic vesicles at the site of release. There are three major differences between cochlear hair cell synapses and CNS synapses: (i) hair cells have a specialized structure, the synaptic ribbon, to which synaptic vesicles are attached; (ii) hair cells can maintain high and sustained release of neurotransmitter; and (iii) hair cells lack synaptophysin and synapsin. These differences suggest that an unconventional mechanism of neurotransmitter release may be involved at ribbon synapses. In this study we used different and complementary approaches to determine whether or not ribbon-containing hair cells of the cochlea express any component of the core fusion complex found in conventional synapses. Syntaxin 1, the synaptic membrane synaptosome-associated protein (SNAP)-25 and vesicle-associated membrane protein (VAMP or synaptobrevin) were found to be present in the organ of Corti of both rat and guinea-pig, as shown by reverse transcription polymerase chain reaction and Western blotting. In situ hybridization and immunocytochemistry showed mRNA and protein expression, respectively, in both inner and outer hair cells. Synaptotagmins I and II, generally considered to play major roles in neurotransmitter release at central synapses, were not detected in the organ of Corti.
\end{abstract}

\section{Introduction}

The organ of Corti contains two types of morphologically distinct sensory hair cells, inner hair cells (IHCs) and outer hair cells (OHCs). IHCs play the primary sensory role in the cochlea, and they synapse on dendrites of type-I spiral ganglion neurons (SGNs), which represent $90-95 \%$ of the SGNs. OHCs are thought to provide some direct sensory input to the CNS and to modify the mechanical properties of the organ of Corti; they form synapses on the remaining 5-10\% of SGNs, which are called type-II SGNs (Spoendlin, 1972; Berglund \& Ryugo, 1987). The lateral efferent system forms synapses on the dendrites of type-I SGNs at the levels of the inner spiral bundle (ISB) and the tunnel spiral bundle, while the medial efferent system forms synapses directly on the OHCs at the level of the outer spiral bundle (OSB) (Warr et al., 1997).

Recent progress in molecular cloning has led to identification of several proteins involved in neuronal neurotransmitter release. Presynaptic membrane-associated proteins include syntaxin (Bennett et al., 1992, 1993) and synaptic membrane synaptosome-associated protein (SNAP)-25 (Oyler et al., 1989). Synaptic vesicle-associated proteins include vesicle-associated membrane protein (VAMP, also known as synaptobrevin) (Elferink et al., 1989), synaptophysin (Jahn et al., 1985; Leube et al., 1987), synapsin (Südhof et al., 1989) and synaptotagmin (Perin et al., 1991; for review, see Südhof \& Rizo,

Correspondence: Dr Saaid Safieddine, NIDCD/NIH, Bldg 36/Room 5D08, 36 Convent Drive MSC-4162, Bethesda, MD 20892-4162, USA.

E-mail: safieddi@nidcd.nih.gov

Received 31 July 1998, revised 30 September 1998, accepted 7 October 1998
1996). Each of these proteins may have several isoforms with differential expression (for review, see Südhof \& Rizo, 1996; Bock $\&$ Scheller, 1997). In the CNS the fusion of synaptic vesicles with presynaptic membranes occurs when the intracellular $\mathrm{Ca}^{2+}$ rises during an action potential; this depends upon protein-protein interactions between presynaptic membrane proteins and the vesicle membrane-associated proteins. Synaptobrevin and synaptotagmin have been shown to form a multiprotein complex with the synaptosomal-associated protein of $25 \mathrm{kDa}$ (SNAP-25) and syntaxin (Söllner et al., 1993a,b; MacMahon \& Südhof, 1995) resulting in the docking of synaptic vesicles at the site of release. Fusion may then be regulated by association with the $N$-ethylmaleimide-sensitive fusion protein (NSF) and soluble NSF attachment proteins (SNAP) (Söllner et al., 1993b). Synaptobrevin, SNAP-25 and syntaxin are known as SNAP receptors (SNAREs) (for review, see Bennett et al., 1993; Scheller, 1995; Südhof, 1995).

As in the CNS, synaptic transmission at IHC-afferent dendrites is chemically mediated and has many properties typical of fast synaptic transmission in the CNS. Membrane depolarization and $\mathrm{Ca}^{2+}$ in the extracellular medium are required for neurotransmitter release (Jenisson et al., 1985; Bobbin et al., 1991; Parson et al., 1994; Hudspeth \& Issa, 1996). The synaptic vesicles are morphologically similar to those in the CNS, and cochlear hair cell synapses have an active zone with a patch of synaptic membrane where synaptic vesicles cluster or are docked. However, there are three major differences between cochlear hair cell synapses and CNS synapses. First, there is a prominent osmophilic dense body, the synaptic ribbon, adjacent to the presynaptic membrane to which synaptic vesicles are 
attached (Gleisner et al., 1973). This structure is also found in a limited number of other cells including retinal photoreceptors and bipolar cells, vestibular hair cells and pinealocyte cells (for review, see Rao-Mirotznik et al., 1995). Secondly, hair cells maintain a high and sustained release of neurotransmitter (Parson et al., 1994; Issa \& Hudspeth, 1996). Thirdly, synaptophysin and synapsin immunoreactivity are absent from cochlear hair cells (Gil-Loyzaga \& Pujol, 1988; Safieddine \& Wenthold, 1997). These differences, and the recent report showing the presence of syntaxin 3 , but not syntaxin 1 , in the synaptic ribbon-containing synapses of the retina (Morgans et al., 1996), suggest that an unconventional mechanism may be involved in neurotransmitter release at ribbon synapses. In order to have a better understanding of the mechanism underlying neurotransmitter release from cochlear hair cells, we analysed hair cells to determine if they express several of the proteins known to play key roles in neurotransmitter release from CNS synapses.

\section{Materials and methods}

\section{Reverse transcription PCR (RT-PCR) analysis}

Fifteen rats (Taconic, Germantown, NY, USA) and 15 guinea-pigs (NCI, Frederick, MD, USA) were deeply anaesthetized with carbon dioxide and decapitated. The cochleas were removed from the temporal bones and further microdissected in cold phosphate-buffered saline (PBS, pH 7.4). The stria vascularis and the spiral ligament were carefully removed, and the organ of Corti was separated from the spiral ganglion. Finally, the spiral ganglion was microdissected from the modiolus. Both the organ of Corti and the spiral ganglion were immediately homogenized using a polytron PT12000 (Brinkmann, Westbury, NY, USA) in the lysis buffer containing RNase/Protein Degrader (Invitrogen, San Diego CA, USA) until complete lysis was obtained. The Micro-Fast Track kit (Invitrogen) was used to extract mRNA according to the manufacturer's instructions. The total amount of mRNA extracted from either 30 spiral ganglia or from 30 organs of Corti $(<1 \mu \mathrm{g})$ was reverse-transcribed into cDNA. The reaction was catalysed by Superscript reverse transcriptase (Gibco-Bethesda Research Labs, Gaithersburg, MD, USA) using an oligo (dT) primer.

PCR was performed as follows: $94{ }^{\circ} \mathrm{C}$ for $45 \mathrm{~s}, 55^{\circ} \mathrm{C}$ for $1 \mathrm{~min}$ and $72{ }^{\circ} \mathrm{C}$ for $2 \mathrm{~min}$ ( 38 cycles). The last cycle was followed by a 10 -min extension at $72{ }^{\circ} \mathrm{C}$. The PCR products were analysed by electrophoresis on $1.5 \%$ agarose gels. Whole brain cDNA made under similar conditions was used as a control. In addition, $\alpha 9$ nicotinic receptor which is selectively expressed in hair cells of the organ of Corti (Elgoyhen et al., 1994) was used as a control for organ of Corti cDNA quality. Primers used to direct PCR amplification of the different cDNAs were designed on the basis of published nucleotide sequences from the rat, using the DNA-STAR program (DNASTAR, Madison, WI, USA) (Table 1). SNAP-25, syntaxin, synaptotagmin, synapsin, synaptophysin and synaptobrevin isoforms were assayed. A set of primers is considered specific when a single specific PCR product is obtained using a cDNA clone as a template. To verify that we were amplifying the correct cDNAs, all PCR products obtained were subcloned, sequenced and compared with published sequences in Gen Bank. The clones obtained by PCR were then used for in vitro transcription to make riboprobes for in situ hybridization.

\section{In situ hybridization}

In vitro transcription and labelling of sense and antisense probes were performed according to established procedures using SP6 and T7 RNA polymerases with $S^{35}$ (New England Nuclear, Boston, MA, USA), using riboprobe in vitro transcription systems (Promega,
TABLE 1. 5'-3' primers used for PCR

\begin{tabular}{|c|c|}
\hline Source & $5^{\prime}-3^{\prime}$ primers \\
\hline \multirow[t]{2}{*}{ SNAP-25 $\alpha$ (GenBank) } & AGGACTTTGGTTATGTTGGATGAG \\
\hline & TCTGGCGATTCTGGGTGTC \\
\hline \multirow[t]{2}{*}{ SNAP-25 $\beta$ (GenBank) } & TGGCATCAGGACTTTGGTTAT \\
\hline & TCTGGCGATTCTGGGTGTC \\
\hline Syntaxin 1 & AACCGCTCCTCCGCTGACCTGA \\
\hline Bennett et al. (1993) & GACACGGCCCTCTCCACATAGT \\
\hline Syntaxin 2 & GCGAAGCAAAGGCCGAATCCAG \\
\hline Bennett et al. (1993) & TGCCAACCGTCAAGCCAATG \\
\hline Syntaxin 3 & CCTCTCCCGGAAGTTTGTGG \\
\hline Bennett et al. (1993) & TTTAGTTTCATCCCGTGCCTTCTC \\
\hline Syntaxin 4 & CATAGAGCCCCAGAAGGAAGAAGC \\
\hline Bennett et al. (1993) & ATGCCAATGATGACAGCCAAGATG \\
\hline Syntaxin 5 & TGCAGAGCCGTCAGAATGGAATC \\
\hline Bennett et al. (1993) & CACTGGCGCCCTGGAGAACTGT \\
\hline Syntaxin 6 & AAGCGTTGGCAGAAAGGAAAAA \\
\hline Bock et al. (1996) & AGGACCGCGAAGAGGATGGCTATG \\
\hline nsec1 & CTGAAGGCGGTGGTAGGGGAAAAA \\
\hline Pevsner et al. (1994) & ATAGGGGAGGAAGGCAAGGTGGAT \\
\hline VAMP1 & TCCTCCTCCCAATACGACCAGT \\
\hline Elferink et al. (1989) & CGAGCAGCATTTCTAGTTTTGAGG \\
\hline VAMP2 & AAGCGCAAATACTGGTGGAAAAAC \\
\hline Elferink et al. (1989) & TTGGGGCTGAACAGGAAAGAGG \\
\hline Synaptotagmin I & CTCCCTCCGCTACGTCCCTACTGC \\
\hline Perin et al. (1991) & GCTCTGCGCCGGTGCTGTTG \\
\hline Synaptotagmin II & CGCCGCACCTGCCGATAACTCTA \\
\hline Geppert et al. (1991) & AGGCCTGTCTCCGCGTCGTCAT \\
\hline Synaptotagmin III & CACCCAGCCCACCATCCACCATTT \\
\hline Mizuta et al. (1994) & CAGAGCCCCCGCCCGTTCG \\
\hline Synaptotagmin IV & CTGTCCCTGCACTTCACCGTCCTG \\
\hline Ullrich et al. (1994) & CCAACCGCCCGATCACCTCATTTC \\
\hline Synaptotagmin V & CCTGACCGGAAAACAAAACACCA \\
\hline Li et al. (1995) & TTCTTCAGTCTCCGGCCATCACAC \\
\hline Synaptotagmin VI & CGGGGCATGAGCGGAGTTTG \\
\hline Li et al. (1995) & TCGGCTGGGATATCTGGGGAAGTA \\
\hline Synaptotagmin VII & AATCTAAACCCGCACTGGAACGAG \\
\hline Li et al. (1995) & CATTGCGGCTGAGCTTGTCTTTG \\
\hline Synaptotagmin VIII & CATGGTTCAACCAGATGTGGACTG \\
\hline Li et al. (1995) & СТCTATCTCTTCAGGCTAGA \\
\hline Synaptotagmin IX (originally V) & GCCCAAGCCCAAGTCCATCT \\
\hline Craxton \& Goedert (1995) & GGCCGCCCCAGGTTCAC \\
\hline Synaptophysin & TTTGCCATCTTCGCCTTTGCTACG \\
\hline Leube, (1987) & TGGCCATCTTCACATCGGACAGG \\
\hline Synapsin 1a & CCCACCCCCACAAGGCCAGCAACA \\
\hline Südhof et al. (1989) & GGTCCCCCGGCAGCAGCAATGATG \\
\hline Synapsin $2 \mathrm{a}$ & GCAGGCCTCCCCAGCATCAA \\
\hline Südhof et al. (1989) & CCAGCATCGCGGAGCCAGTGTTT \\
\hline
\end{tabular}

Madison, WI, USA). Labelling reactions were performed as suggested by the manufacturers.

Male Sprague-Dawley rats $(n=5 ; 150-200 \mathrm{~g})$ and male pigmented guinea-pigs $(n=11 ; 200-250 \mathrm{~g})$ were used. Animals were deeply anaesthetized with a $1: 1$ mixture of ketamine hydrochloride (Ketaset; $100 \mathrm{mg} / \mathrm{mL}$; Aveco, Fort Dodge, IA, USA) and xylazine (Rompun; $20 \mathrm{mg} / \mathrm{mL}$; Mobay Corp., Shawnee, KS, USA) and perfused through the heart with $10 \mathrm{~mL}$ of PBS at room temperature, followed by $250 \mathrm{~mL}$ of ice-cold $4 \%$ paraformaldehyde in $1 \times \mathrm{PBS}$ at $\mathrm{pH} 7.4$. The cochleas were further perfused through the round window with the same fixative solution, postfixed overnight and then rinsed for 48 $72 \mathrm{~h}$ in phosphate buffer containing 5\% EDTA and 4\% paraformaldehyde. They were then washed overnight in phosphate buffer containing $20 \%$ sucrose and frozen in isopentane at $-60{ }^{\circ} \mathrm{C}$. The cochleas were cut on a cryostat into $10 \mu \mathrm{m}$-thick sections and stored at $-70{ }^{\circ} \mathrm{C}$ until use.

The in situ hybridization method described in this study is a modification of a previously described protocol (Safieddine \& Wenthold, 1997). Sections were washed with PBS containing 0.5\% Triton 
$\mathrm{X} 100(\mathrm{w} / \mathrm{v})$ for $30 \mathrm{~min}$ at room temperature and acetylated with $0.25 \mathrm{M}$ acetic anhydride in $0.1 \mathrm{M}$ triethanolamine $/ 0.9 \% \mathrm{NaCl}$ for $10 \mathrm{~min}$ at room temperature and then dehydrated in an ascending series of ethanol and air-dried for $1 \mathrm{~h}$ at room temperature. The probes were heated at $80^{\circ} \mathrm{C}$ for $5 \mathrm{~min}$ and were diluted to $10^{6} \mathrm{c}$ c.p.m./ $\mathrm{mL}$ in hybridization buffer [50\% formamide, $2 \times$ standard saline citrate (SSC; $1 \times \mathrm{SSC}$, in $\mathrm{M}$ : $\mathrm{NaCl}, 0.15$; sodium citrate, 0.15$), 1 \mathrm{~mm}$ Tris $\mathrm{HCl}, \mathrm{pH} 7.5,1 \times$ Denhart's solution, $10 \%$ dextran sulphate, $100 \mathrm{~mm}$ dithiothreitol (DTT), $500 \mu \mathrm{g} / \mathrm{mL}$ sheared single-stranded salmon sperm DNA and $250 \mathrm{mg} / \mathrm{mL}$ yeast transfer RNA]. The labelled sense riboprobe was used as a control. Hybridization was performed overnight at $60{ }^{\circ} \mathrm{C}$. The sections were washed in $4 \times \mathrm{SSC}$ (four times, $5 \mathrm{~min}$ each) prior to ribonuclease A treatment $(20 \mathrm{mg} / \mathrm{mL}$ for $30 \mathrm{~min}$ at $37^{\circ} \mathrm{C}$ ). The slides were rinsed in decreasing concentrations of SSC containing $1 \mathrm{~mm}$ DTT to a final stringency of $0.1 \times$ SSC containing $1 \mathrm{~mm}$ of DTT for $1 \mathrm{~h}$ at $60^{\circ} \mathrm{C}$. Sections were dehydrated and dried, and then either exposed to Kodak B MAX X-ray film for 6 days or coated with NTB2 photographic emulsion at $4{ }^{\circ} \mathrm{C}$ and exposed for $4-5$ weeks. The sections were counterstained through the emulsion using a $1 \%$ solution of thionin.

\section{Western blot analysis}

Electrophoresis was carried out according to the method of Laemmli (1970) using gels $8 \mathrm{~cm}$ in length with an acrylamide gradient of 4-20\%. Proteins were transferred to nitrocellulose membranes as described by Towbin et al. (1979). Membranes were incubated overnight with $5 \%$ nonfat dry milk in Tris-buffered saline-Tween (in mM: Tris, 50; $\mathrm{NaCl}, 150, \mathrm{pH} 7.4$, containing $0.05 \%$ Tween 20). Antibodies were diluted as suggested by the manufacturers, and bound antibody was detected using either alkaline phosphatase (Kirkegaard and Perry Laboratories, Inc., Gaithersburg, MD, USA) or chemiluminescence (New England Nuclear). Prestained molecular weight standards from Gibco-Bethesda Research Labs were myosin, phosphorylase b, bovine serum albumin (BSA), ovalbumin, carbonic anhydrase, $\beta$-lactoglobulin and lysozyme, migrating at $M_{\mathrm{r}}=203000,105000,71000$, $44600,28000,18000$ and 15000 , respectively.

\section{Immunocytochemistry}

The fixation procedure and tissue preparation were the same as described above for in situ hybridization. Briefly, the tissue sections were rinsed $3 \times 20 \mathrm{~min}$ in PBS containing $0.2 \%$ BSA and then preincubated for $1 \mathrm{~h}$ in PBS-BSA with $30 \%$ normal goat serum. Preincubation buffer was removed, and the primary antibodies were applied to the sections. After $24 \mathrm{~h}$ incubation at $4{ }^{\circ} \mathrm{C}$, the sections were rinsed in PBS-BSA $(3 \times 20 \mathrm{~min})$ and incubated for $2 \mathrm{~h}$ with secondary antibody conjugated to dichlorotriazinyl aminofluorescein (DTAF, Boehringer Mannheim, Germany). The sections were then rinsed in PBS $(3 \times 20 \mathrm{~min})$ and mounted in FluorSave medium (Calbiochem, San Diego, CA, USA).

All animals used in this study were maintained in accordance with the National Institutes of Health Guide for the Care and Use of Laboratory Animals (NIH Publication no. 85-23).

\section{Results}

\section{$R T$-PCR analysis}

A relatively pure preparation of the organ of Corti, which includes the sensory hair cells (IHC and OHCs), the Deiter's cells, Hensen cells and Claudius cells, can be obtained by microdissection. Since this represents a very small amount of tissue (30 organs of Corti yield $<1 \mu \mathrm{g}$ mRNA), we used RT-PCR as the primary screening
TABLE 2. v- and t-SNAREs detected in the organ of Corti by RT-PCR

\begin{tabular}{lcc}
\hline SNARE & Spiral ganglion & Organ of Corti \\
\hline Syntaxin 1 & + & + \\
Syntaxin 2 & + & - \\
Syntaxin 3 & + & - \\
Syntaxin 4 & + & - \\
Syntaxins 5 and 6 & + & + \\
SNAP-25 $\alpha$ & + & + \\
SNAP-25 $\beta$ & + & - \\
nsec1 & + & + \\
VAMP1 & + & + \\
VAMP2 & + & - \\
Synaptotagmins I-III and V & + & - \\
Synaptotagmin IV & + & + \\
Synaptotagmin VI & + & + \\
Synaptotagmin VII & + & + \\
Synaptotagmin VIII & + & + \\
Synaptotagmin IX & + & + \\
Synaptophysin & + & - \\
Synapsin I, II & + & \\
\hline
\end{tabular}

method. As an indicator of the quality of the mRNA extracted from the organ of Corti, we used the amplification of $\alpha 9$ nicotinic receptor cDNA which is selectively expressed in cochlear hair cells (Elgoyhen et al., 1994; Park et al., 1997). Brain tissue from both rat and guineapig was used as a positive control for RT-PCR analysis. RT-PCR results are summarized in Table 2 and selected gels are illustrated in Fig. 1. PCR products at the expected size of syntaxin 1, VAMP1 and SNAP-25 were obtained for organ of Corti as well as for the brain and spiral ganglion. Among the SNAREs that comprise the core fusion complex in the CNS, VAMP2 was not detected in the organ of Corti but was present in the spiral ganglion (Fig. 1). Similarly, synaptotagmins I, II, III and V were not detected in the organ of Corti. These negative results were verified using multiple primers for PCR, all of which gave a product of the expected size for both guinea-pig and rat brain. Synaptotagmins IV, VI, VII, VIII and IX are, however, expressed in both the organ of Corti and the spiral ganglion (data not shown). Syntaxin 3, which has been implicated as an element of the fusion core complex in the retina (Morgans et al., 1996), was not detected in organ of Corti. Syntaxins 5 and 6 are expressed in both the organ of Corti and the spiral ganglion (data not shown). Synaptophysin and synapsin are present in the spiral ganglion, but they are not detected in the organ of Corti.

\section{In situ hybridization}

RT-PCR analysis showed that syntaxin 1, VAMP1 and SNAP-25 were present in the organ of Corti mRNA extract. Since these proteins are essential components of the core fusion complex in the CNS, we investigated their cellular expression within the organ of Corti by using their corresponding riboprobes. Controls included incubation with the corresponding sense riboprobe and analysis of the distribution in brain (SNAP-25 and VAMP1) for comparison with published data (Oyler et al., 1989; Trimble et al., 1990). The antisense riboprobe showed that SNAP-25 is highly expressed in all cell types of the organ of Corti, including the spiral limbus (Fig. 2A and B). However, the expression of syntaxin 1 and VAMP1 seemed to be restricted to the sensory hair cells, including IHCs and OHCs (Figs 3A and 4A). As expected from RT-PCR analysis, SNAP-25 (Fig. 2A), syntaxin 1 (Fig. 3B) and VAMP1 (Fig. 4B) were highly expressed in the SGNs. In both hair cells and SGNs, the hybridization signal was uniform throughout all the cochlear turns, with no indication of a turndependent expression pattern. Only background levels were observed in sections hybridized with SNAP-25 and syntaxin 1 sense riboprobes 

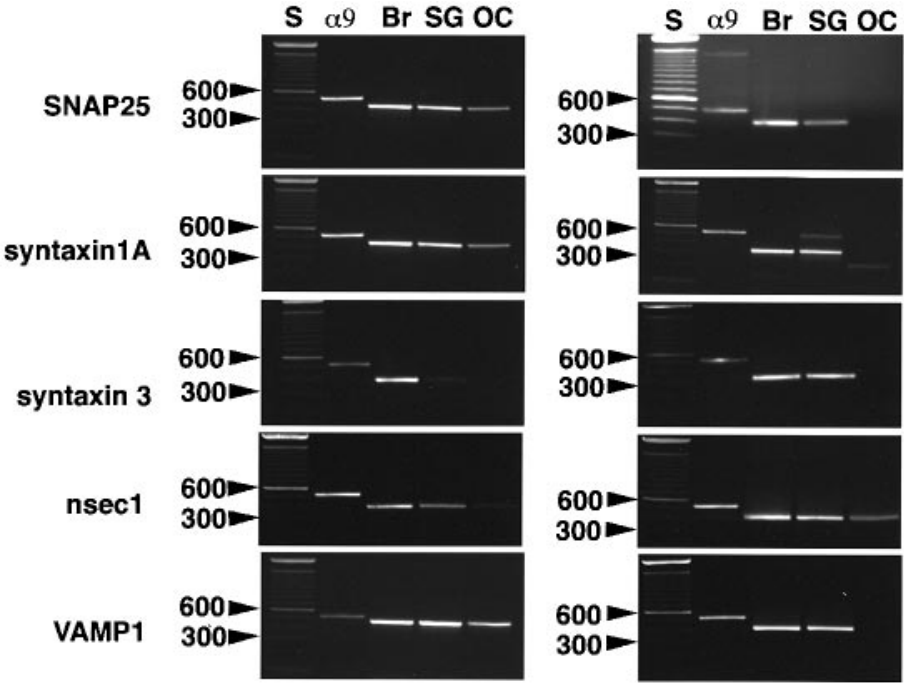

VAMP2

synaptotagmin I

synaptotagmin II

FIG. 1. Agarose gel electrophoresis of PCR products amplified from rat brain, guinea-pig organ of Corti and spiral ganglion with specific primers. A pattern similar to that of the rat brain was obtained for guinea-pig brain (data not shown). Lane S, 100-bp standard; lane $\alpha 9$, $\alpha 9$ nicotinic receptor from organ of Corti cDNA; lane Br, Brain; lane SG, spiral ganglion; and lane $\mathrm{OC}$, organ of Corti. The bands are labelled in units of $100 \mathrm{bp}$ (100-bp DNA ladder standard, Gibco-BRL).
(Figs 2C, 3C). As expected from RT-PCR results, sections hybridized with synaptotagmin I antisense riboprobe showed no hybridization signal in the organ of Corti (Fig. 5A), while a strong signal was observed in the SGNs (Fig. 5B).

\section{Western blot analysis}

As SNAP-25, syntaxin 1 and VAMP1 are components of the core fusion complex, and transcripts were detected in the organ of Corti, we extended our study to the proteins in order to verify the expression and determine their localizations. An immunopositive band of the expected size, which co-migrated with the major band obtained from rat brain, was found for each protein (Fig. 6). For each protein, results were verified using at least two different antibodies. Because guineapigs were used in this study, before using the antibodies for immunocytochemistry, it was necessary to determine their specificities on Western blots of organs of Corti homogenates. This showed that the following antibodies were most appropriate for immunocytochemistry: SNAP-25 (Sternberger, Baltimore, MD, USA), syntaxin 1 (Wako, Richmond, VA, USA) and VAMP (StressGen, Victoria, BC, Canada).

\section{Immunocytochemistry}

In the organ of Corti, the immunoreactivity to SNAP-25 was high in the IHCs and moderate-to-low in the OHCs. This immunostaining was uniformly distributed throughout the cochlear turns (Fig. 7A and B). Both ISB and OSB were intensely immunostained (Fig. 7A and $B)$. At the medial efferent level, the immunoreactivity was seen along the entire OSB (Fig. 7A and B). The sympathetic fibers in the modiolus were also immunoreactive to SNAP-25. In the spiral ganglion, all the SGNs were immunoreactive to SNAP-25 antibody. SGNs characteristic of type-II SGNs (small size and located at the periphery of the spiral ganglion) were also immunoreactive (Fig. 7C). Immunoreactivity to syntaxin 1 and VAMP antibodies in the organ of Corti was intense and concentrated in the sensory hair cells (IHCs and $\mathrm{OHCs}$ ) (Figs 8A and 9A). In addition, this immunoreactivity was turn-dependent, being high in the basal turn and decreasing towards the apex (Figs 8A and $\mathrm{B}$, and $9 \mathrm{~A}$ and $\mathrm{B}$ ). Compared with the immunoreactivity pattern of SNAP-25, which was seen along the axons and at the basal pole of the OHCs (Fig. 7A and B), the immunoreactivity to syntaxin (Fig. 8A and B), VAMP1/2 (Fig. 9A and B) and VAMP2 (Fig. 8C) was concentrated under the OHCs where the OSB makes synapses with the OHCs. The immunostaining obtained with VAMP1/2 and VAMP2 antibodies was clearly different. With VAMP1/2 the immunoreactivity was seen in the sensory hair cells, ISB and OSB (Fig. 9A and B), while with VAMP2, the immunoreactivity was seen in both the OSB and the ISB, and was essentially undetectable in sensory cells (Fig. 9C). As seen with SNAP-25, in the spiral ganglion, all the type-I and type-II SGNs were immunolabelled with both VAMP (data not shown) and syntaxin antibodies (Fig. 9C). As expected from RT-PCR and in situ hybridization results, the hair cells were not immunoreactive to synaptotagmin antibody, while intense immunolabelling was observed in both the ISB and the OSB (Fig. 5C).

\section{Discussion}

The objective of this study was to determine if the functional and morphological differences observed in ribbon-containing sensory cells of the inner ear are associated with differences in expression of several of the key proteins involved in neurotransmitter release. Our results point to many similarities as well as differences between hair cells and neurons and also between hair cells and ribbon-containing cells of the retina. First, we find that syntaxin 1, the predominant syntaxin at CNS synapses, is also expressed in hair cells. Syntaxin 3 , which is present at ribbon-containing synapses in the retina, was not detected in the organ of Corti. Secondly, VAMP 1, but not VAMP 2 which is associated with ribbon synapses of the retina, is expressed in hair cells. Thirdly, we were unable to detect synaptotagmins I and II in hair cells. These are believed to be the principal synaptotagmins involved in neurotransmitter release at CNS synapses.

\section{The SNARE complex of the ribbon-containing hair cell synapse}

RT-PCR, in situ hybridization and immunocytochemistry data all show that the ribbon-containing cochlear hair cells express SNAP25 , syntaxin 1 and VAMP1. The intensity of the in situ hybridization signal was similar in both IHCs and OHCs, while protein expression was significantly lower in the OHCs. In addition, immunoreactivity to syntaxin 1 and VAMP1 was turn-dependent, with higher staining in the basal turn (Figs 9A and 10A) and a decrease towards the apex (Figs 9B and 10B). This pattern was not observed with in situ hybridization. A postranscriptional regulation could explain such variation, and this would be in agreement with the recent report 

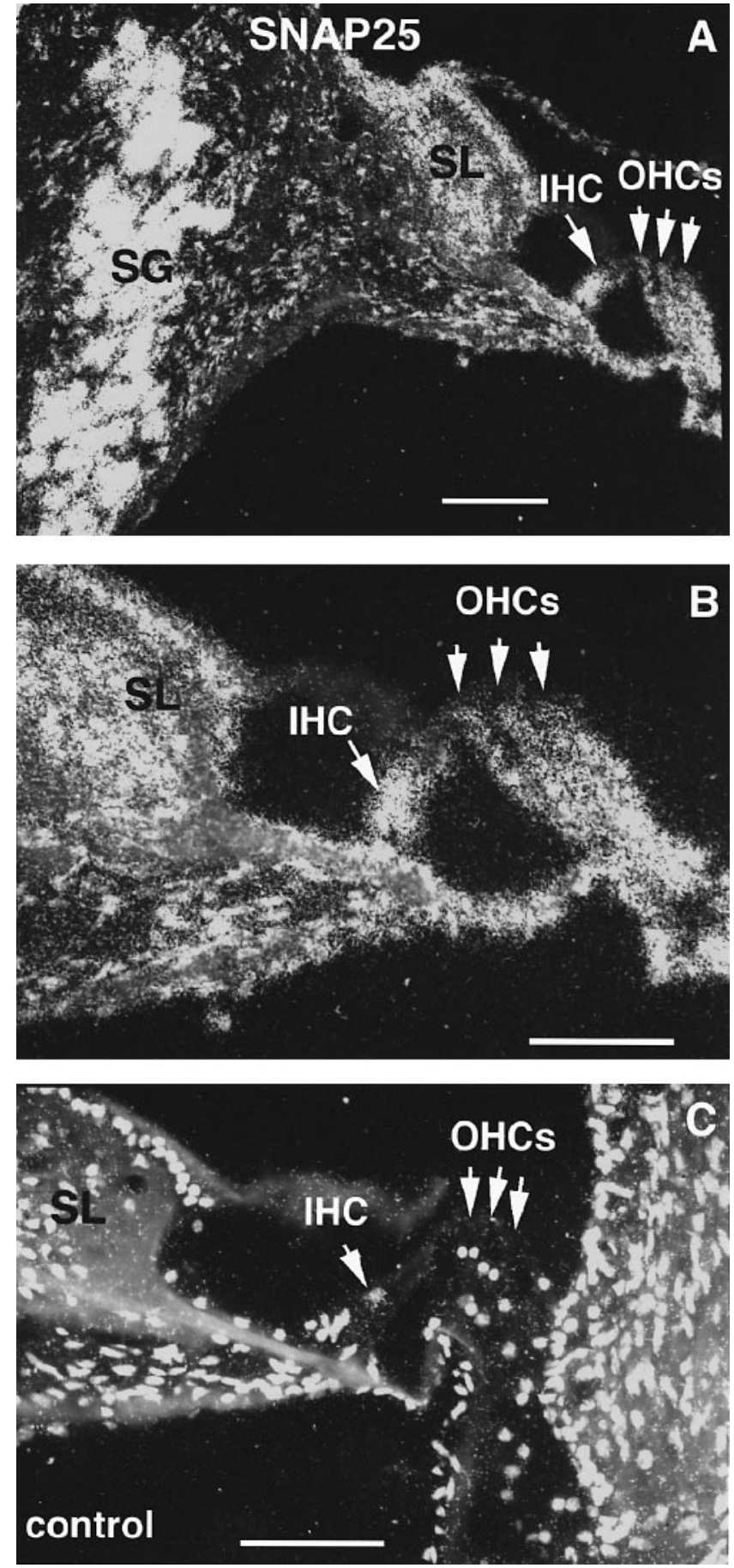

FIg. 2. Sections through the second turn (A, B and C) of the guinea-pig cochlea. Only background signal is seen in section $\mathrm{C}$, hybridized with SNAP25 sense riboprobe. Sections A and B hybridized with SNAP-25 antisense riboprobes show an intense positive hybridization signal in sensory hair cells (OHCs and IHC), in the spiral ganglion neurons (SG) and in the spiral limbus (SL). Scale bars, $100 \mu \mathrm{m}$.

showing that the production of synaptic vesicle proteins is not limited by the rates of gene transcription but rather by a cytoplasmic mechanism (Daly \& Zip, 1997). This could also explain the in situ hybridization signal seen with SNAP-25 in the spiral limbus (Fig. 3A and $\mathrm{B}$ ) in which no immunoreactivity was detected (Fig. 8A and B). The greater abundance of SNARE proteins in IHCs would be consistent with the fact that IHC synapses are considered to be more
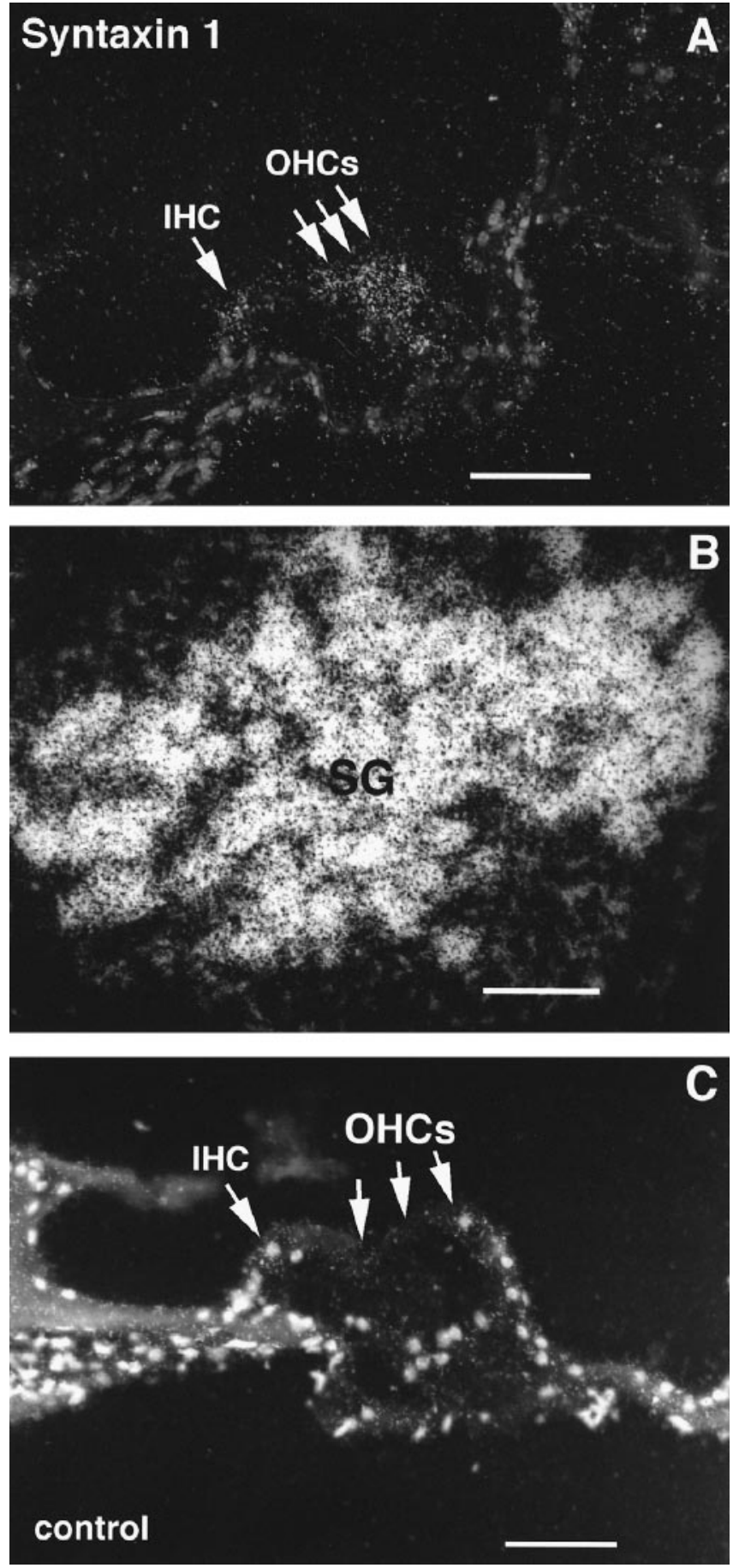

FIG. 3. Sections through the second turn of the organ of Corti (A and C) and third turn of the spiral ganglion (B) of the guinea-pig cochlea. In section C, incubated with syntaxin 1A sense riboprobe, none of the organ of Corti cells displays a hybridization signal above the background. Sections A and B, hybridized with the antisense riboprobe, show a strong hybridization signal, which seems to be restricted to the hair cells (A) and SGNs (B). Scale bars, $100 \mu \mathrm{m}$.

active than OHCs. Most of the SGNs (90-95\%) form synapses on IHCs (Spoendlin, 1972; Berglund \& Ryugo, 1987), and IHC-SGN synapses have a higher concentration of glutamate receptors on their postsynaptic membranes than do OHC-SGN synapses (Matsubara et al., 1996).

Based on the immunostaining, SNAP-25, syntaxin 1, and VAMP1 

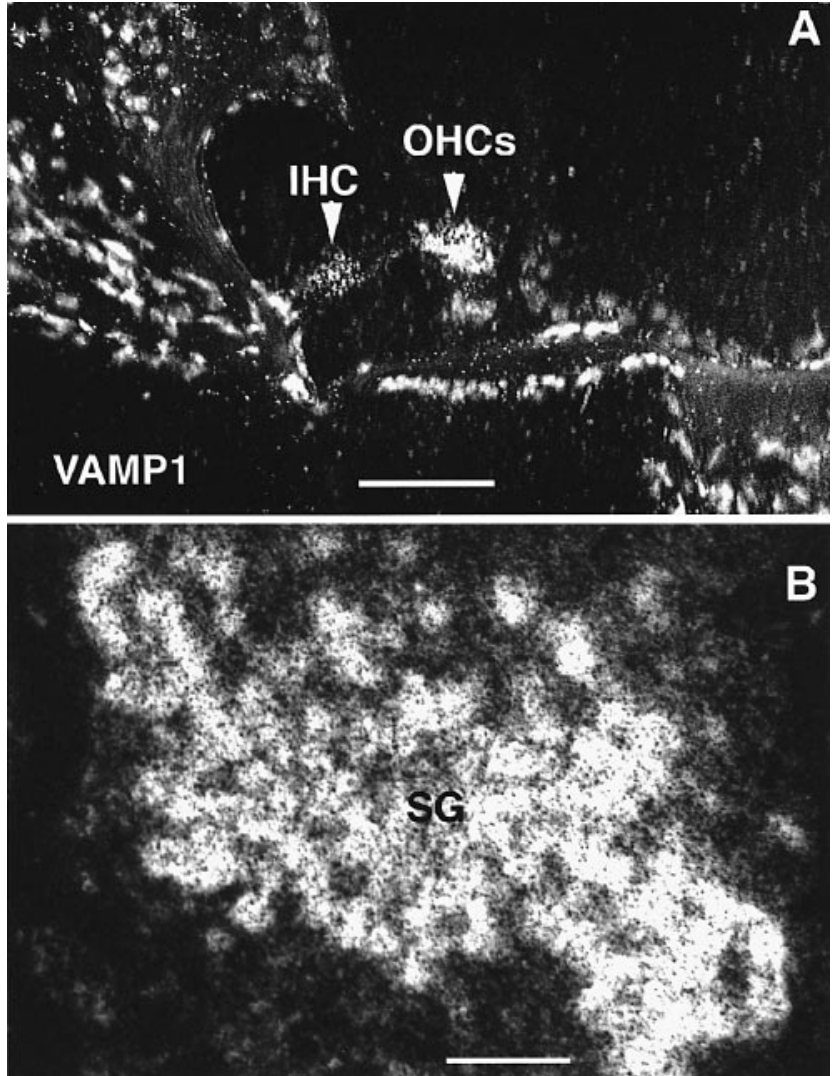

FIG. 4. Sections through the third turn of the organ of Corti (A) and the second turn of the spiral ganglion (B) of the guinea-pig cochlea. Sections, hybridized with VAMP1 antisense riboprobe, display an intense hybridization signal in the hair cell area (A) and in the SGNs (B). Scale bars, $50 \mu \mathrm{m}$.

do not appear to be concentrated at the base of the hair cell where synaptic contacts are made, but rather are found throughout the cell. A similar general pattern of staining has been reported for other cells (Garcia et al., 1995; Rossetto et al., 1996). In OHCs, immunolabelling, particularly for VAMP1, is concentrated below the cuticular plate (Fig. 9B). This may suggest an additional role for VAMP1 in hair cells, or may simply reflect a targeting mechanism in hair cells that does not involve a direct route to the synaptic area.

Our in situ hybridization and immunocytochemical results indicate that syntaxin 1 is expressed in hair cells. Two additional findings support a functional role for syntaxin 1 , but not syntaxin 3 , in neurotransmitter release from hair cells. (i) The syntaxin binding protein, nsec1, is expressed in the organ of Corti, according to RTPCR, and immunocytochemistry shows that it is present in hair cells (data not shown). It is known that nsec1 binds strongly to syntaxin 1 (Pevsner et al., 1994; Hata \& Südhof, 1995; for review, see Pevsner, 1995), and this interaction inhibits the binding of syntaxin to SNAP25 (Pevsner et al., 1994). (ii) VAMP1 is expressed in the hair cells, and VAMP1 binds specifically to syntaxin 1, but not to syntaxin 3 (Calakos \& Scheller, 1994; Kee et al., 1995). The absence of synaptophysin from hair cells is in agreement with the fact that only VAMP2, but not VAMP1, forms a complex with synaptophysin (Calakos \& Scheller, 1994; Washbourne et al., 1995; Galli et al., 1996). It has been proposed that the synaptophysin/VAMP2 interaction may have a regulatory role on SNARE complex formation (Edelmann et al., 1995). VAMP2 (Morgans et al., 1996) and synaptophysin (Brandstätter et al., 1996) are both expressed in photoreceptors and retinal bipolar cells. The absence of synaptophysin in hair cells raises
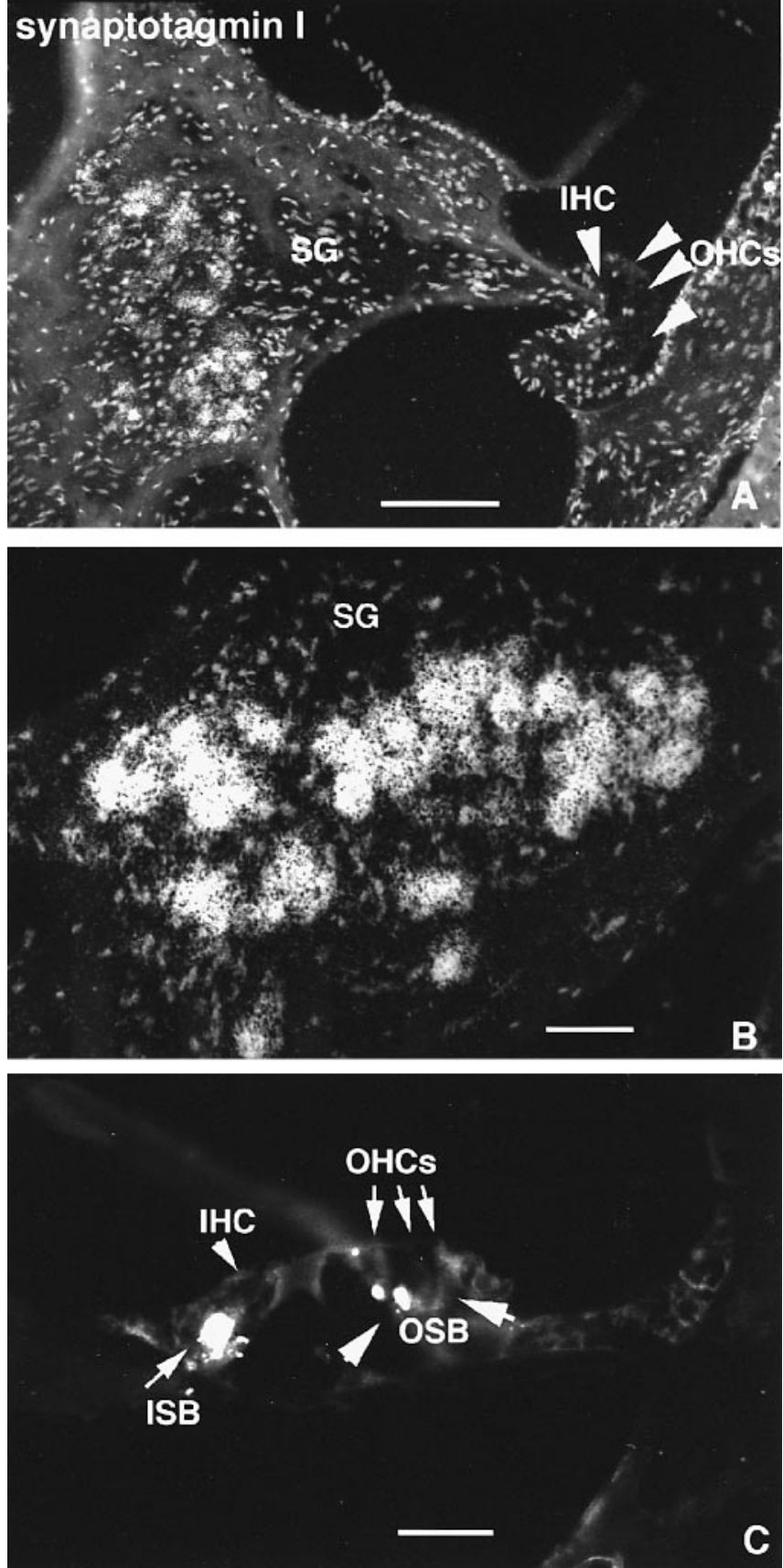

FIG. 5. Sections through the basal (A and C) and third turn (B) of the organ of Corti and spiral ganglion, respectively. Sections A and B were hybridized with synaptotagmin I antisense riboprobe. No signal is detected in any cell of the organ of Corti (A). A convincing and intense signal is observed in the SGNs (B). Section C, incubated with synaptotagmin antibody, shows that the hair cells of the organ of Corti do not display any immunoreactivity, although an intense immunolabelling is seen in ISB and OSB. Scale bars, $100 \mu \mathrm{m}$.

the possibility of the existence of an unknown synaptophysin isoform, which interacts with VAMP1.

The SNARE complex of the ribbon-containing synapses of hair cells differs from that of retinal bipolar cells and photoreceptors

Based on the different properties of exocytosis of neurotransmitter from ribbon synapses and conventional synapses, it has been proposed that ribbon synapses are designed to optimize a sustained high rate 


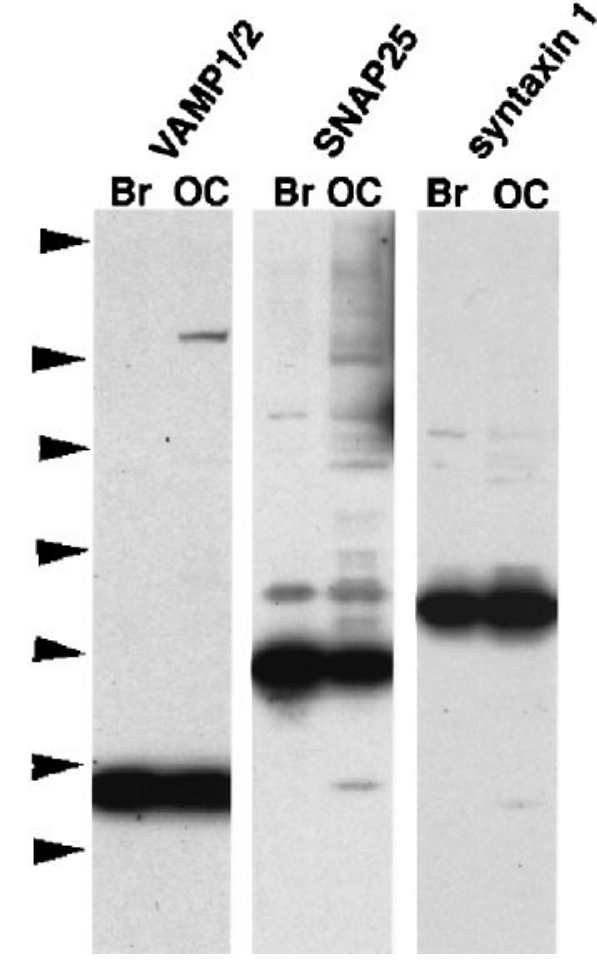

FIG. 6. Western blot of rat brain $(\mathrm{Br})$ and guinea-pig organ of Corti (OC) homogenates probed with antibodies to VAMP1/2, syntaxin 1 and SNAP-25. With the three antibodies, the same major immunoreactive band seen in $\mathrm{Br}$ is also observed in the $\mathrm{OC}$ of the guinea-pig. A similar pattern was obtained for guinea-pig brain (data not shown). Arrowheads show the position of prestained standards myosin $\left(M_{\mathrm{r}}=203000\right)$, phosphorylase b $\left(M_{\mathrm{r}}=105000\right)$, BSA $\left(M_{\mathrm{r}}=71000\right)$, ovalbumin $\left(M_{\mathrm{r}}=44600\right)$, carbonic anhydrase $\left(M_{\mathrm{r}}=28000\right)$, $\beta$-lactoglobin $\left(M_{\mathrm{r}}=18000\right)$ and lysozyme $\left(M_{\mathrm{r}}=15000\right)$.

of neurotransmitter release, and therefore a similar mechanism may be used at all ribbon synapses (for review, see Juusola et al., 1996). We show in the present study that, except for the expression of SNAP-25 and the absence of synapsins in these synapses, the expression of most major SNARE complex proteins differs between cochlear hair cells and the ribbon-containing photoreceptors and bipolar cells. These differences include the following. (i) Hair cells express syntaxin 1 and VAMP1, but not syntaxin 3 and VAMP2. In the retina, photoreceptors and bipolar cells express syntaxin 3 and VAMP2, but not syntaxin 1 and VAMP1. (ii) As has been previously demonstrated (Gil-Loyzaga \& Pujol, 1988; Safieddine \& Wenthold, 1997) and confirmed here, synaptophysin is not expressed in cochlear hair cells, but is found in both photoreceptors and bipolar neurons of the retina. (iii) Synaptotagmin I and II are expressed in retinal ribboncontaining cells, but we did not find them expressed in cochlear hair cells. Therefore, while all ribbon synapses may have some properties in common, the actual proteins involved in neurotransmitter release are not the same, suggesting that other functional characteristics may play a greater role in determining protein expression and proteinprotein interactions that lead to neurotransmitter release.

The interaction between SNARE proteins and presynaptic $\mathrm{Ca}^{2+}$ channels has recently been reported. Syntaxin 1 binds to N-type and Q-type $\mathrm{Ca}^{2+}$ channels and this interaction may influence $\mathrm{Ca}^{2+}$ entry at the release sites (Shen et al., 1994; Bezprozvanny et al., 1995). An interaction with other types of $\mathrm{Ca}^{2+}$ channels has not been reported. While the L-type $\mathrm{Ca}^{2+}$ channels are the best characterized of the ribbon synapse $\mathrm{Ca}^{2+}$ channels (hair cells, photoreceptors, bipolar cells and pineal cells) (Fuchs et al., 1990; Rieke \& Schwartz, 1994),
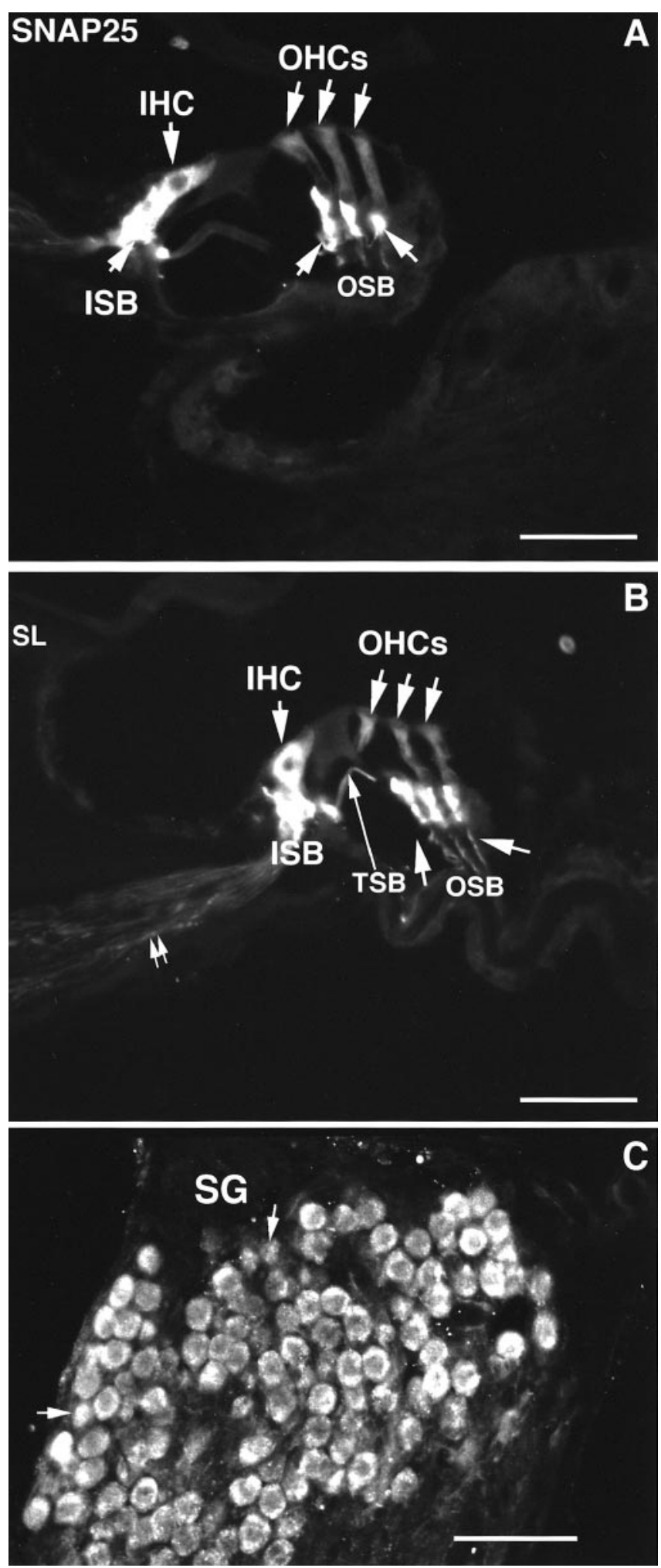

FIG. 7. Sections through the second (A) and apical turn (B) of the organ of Corti or basal turn of spiral ganglion (C) of the guinea-pig cochlea incubated with SNAP-25 antibodies diluted at 1:2000. The immunoreactivity was visualized with a fluorescein-labelled secondary antibody. The IHC, ISB, tunnel spiral bundle (TSB) and OSB are intensely immunoreactive. At the level of the OHCs, moderate immunoreactivity is seen. In this case there are no turn-dependent differences in immunoreactivity. All SGNs of the spiral ganglion (SG) display an intense immunoreactivity to SNAP-25 antibody, including presumptive type-II SGNs (arrows) (C). In B, the double arrow indicates immunoreactivity to SNAP-25 antibody in the sympathetic fibers of the modiolus. Scale bars, $100 \mu \mathrm{m}$. 

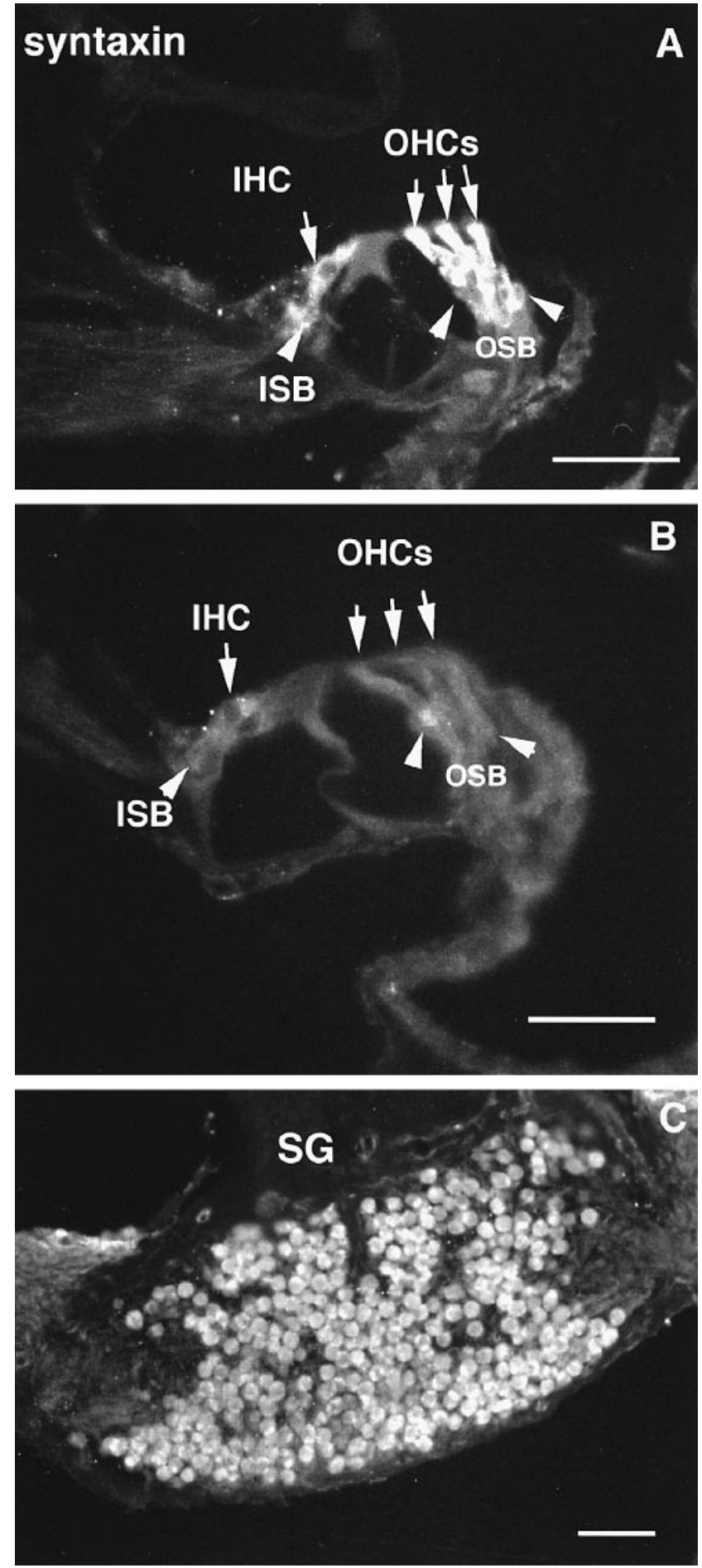

FIG. 8. Sections through the second (A) and apical turns (B) of the guinea-pig cochlea incubated with syntaxin 1 antibody diluted $1: 1500$. The immunoreactivity was visualized with a fluorescein-labelled secondary antibody. In both cases, the IHC, the ISB and the OSB below the OHCs are immunoreactive. In the basal turn (A) the IHC and OHCs display a high immunoreactivity, while in the apical turn (B) low immunoreactivity is seen. All SGNs are immunoreactive (C). Scale bars, $100 \mu \mathrm{m}$ (A and B) and $50 \mu \mathrm{m}(\mathrm{C})$.

there is evidence that $\mathrm{N}$-type $\mathrm{Ca}^{2+}$ channels are also expressed in hair cells ( $\mathrm{Su}$ et al., 1995). Thus, similar mechanisms leading to an increase in $\mathrm{Ca}^{2+}$ concentration at the release site may be involved in the CNS and cochlear hair cells. However, the absence of syntaxin 1 from retinal cells would suggest that such an interaction would not
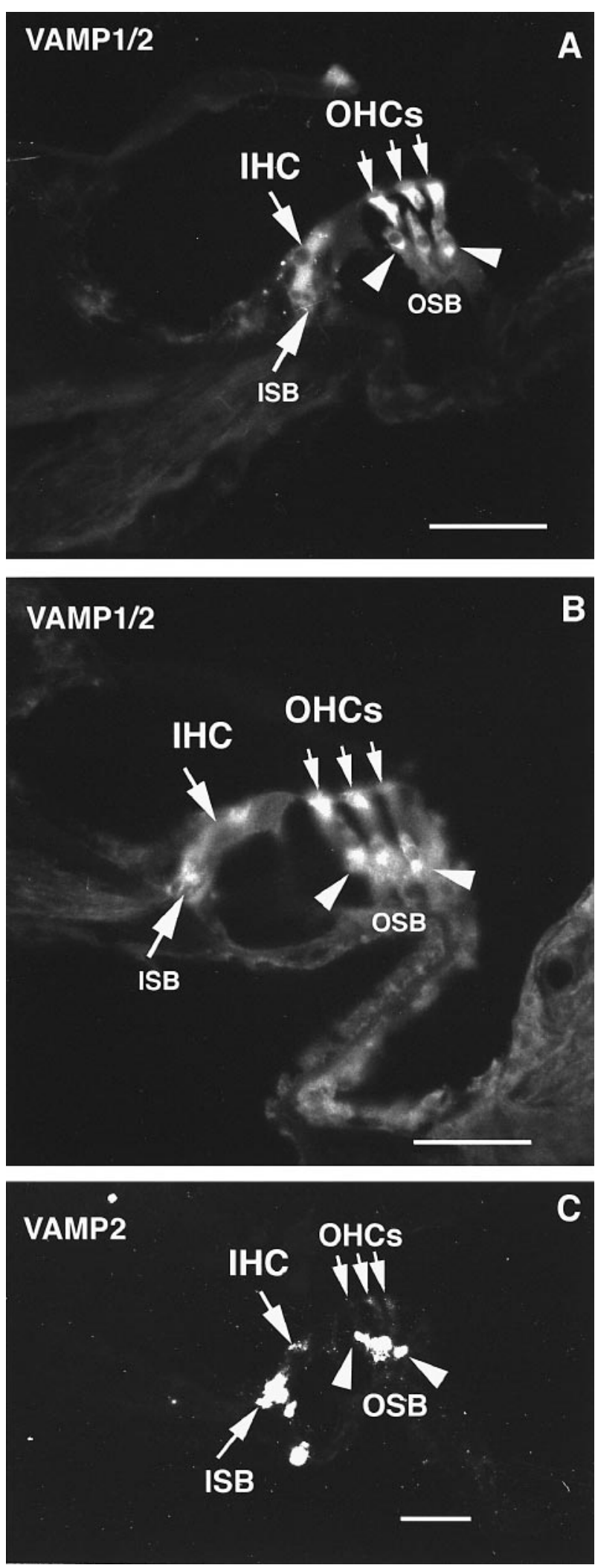

FIG. 9. Sections through the second (A and C) and third turn (B) of the organ of Corti of the guinea-pig. Sections A and B were incubated with VAMP1/2 antibodies diluted $1: 1000$. In C, section was incubated with VAMP2 antibody diluted $1: 500$. The immunoreactivity was visualized with a fluoresceinlabelled secondary antibody. In A and B the IHCs, the ISB and the OSB below the OHCs are immunoreactive. The OHCs are immunoreactive in a turn-dependent manner, i.e. high in the second turn (A) and low-to-moderate in the third turn (B). In C, the immunoreactivity is concentrated in ISB and $\mathrm{OSB}$, while it is very weak in the sensory hair cells. Scale bars, $100 \mu \mathrm{m}$. 


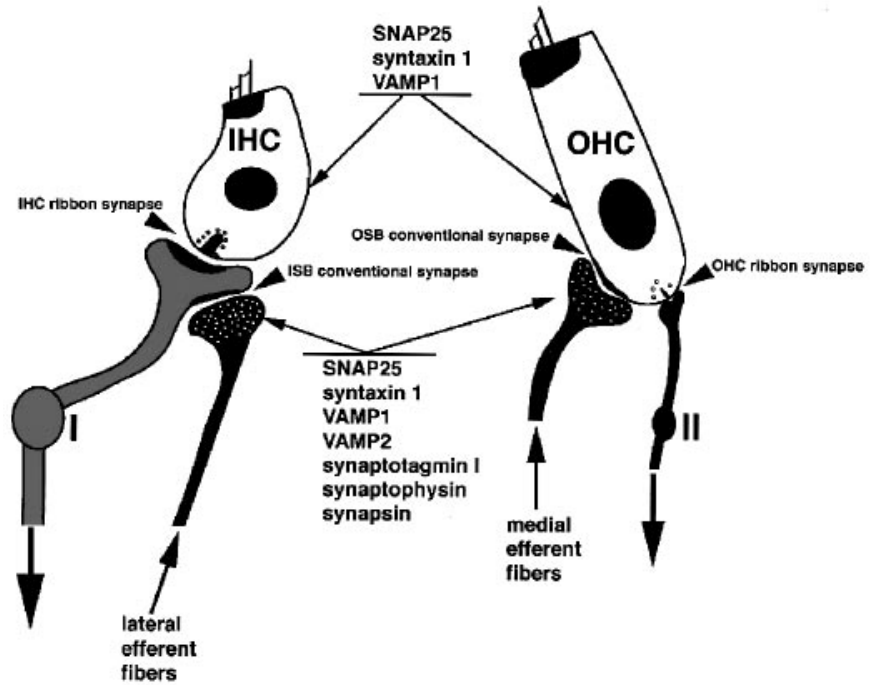

FIG. 10. Illustration of the key proteins that may be present in SNARE complexes in both conventional and ribbon synapses of the cochlea.

occur in these cells. There are no reports indicating whether or not syntaxin 3 interacts with $\mathrm{Ca}^{2+}$ channels, but the domain of syntaxin 1 which interacts with the N-type and Q-type $\mathrm{Ca}^{2+}$ channels is not highly conserved in syntaxin 3 (Bennett et al., 1993)

\section{Synaptotagmin expression in hair cells}

We were unable to demonstrate expression of synaptotagmins I, II, III and V in the organ of Corti. Synaptotagmins I and II are the major forms of synaptotagmin suggested to be involved in neurotransmitter release at conventional synapses, and they are expressed in photoreceptors (Ullrich \& Südhof, 1994). Synaptotagmin I is one of the most intensively studied proteins in the presynaptic nerve terminal, and has been shown to interact with syntaxin 1 (Chapman et al., 1995). The binding site for synaptotagmin on syntaxin 1 has been mapped in detail (Kee \& Scheller, 1996). More recently, studies using lysed synaptosomal membrane preparations or neurotoxin-treated synapses indicate that SNAP-25 and synaptotagmin are involved in triggering neurotransmitter release (Schiavo et al., 1997). Our findings raise the possibility that the ribbon synapses of hair cells may have either a novel synaptotagmin, or synaptotagmin-like molecule, or that a synaptotagmin not thought to play a role in neurotransmission has such a role in hair cells. The latter possibility is supported by our finding of the expression of synaptotagmins IV and VI-IX in hair cells. It has been proposed that these synaptotagmins may be involved in functions performed at low $\mathrm{Ca}^{2+}$ concentrations such as a constitutive exocytosis or recycling of vesicles (for review, see Südhof, 1995; Südhof \& Rizo, 1996). The possibility of a novel synaptotagmin or synaptotagmin-like molecule would not be unexpected since 10 members of this family have already been described. However, our attempts to identify such a molecule did not produce any viable candidates (unpublished data).

In conclusion, our results suggest that the ribbon synapse SNARE complex of cochlear hair cells is composed of syntaxin 1, SNAP-25 and VAMP1. This is dramatically different from the complex expected in ribbon synapses of retinal cells, which contain syntaxin 3, SNAP25 and VAMP2. In addition, hair cells do not express synaptotagmin I or II, or synaptophysin, all of which are present in retinal photoreceptors. The absence of synapsin, synaptophysin, VAMP2 and synaptotagmins I and II in cochlear hair cells also makes the hair cell ribbon synapse different from the conventional synapse.

\section{Acknowledgements}

We thank Dr R.H. Scheller for providing us with the cDNA clones and Drs R.S. Petralia, J.P. Pevsner and P.A. Roche for their comments on this manuscript.

\section{Abbreviations}

BSA, bovine serum albumin; DTT, dithiothreitol; IHC, inner hair cell; ISB, inner spiral bundle; NSF, $N$-ethylmaleimide-sensitive fusion protein; OHC, outer hair cell; OSB, outer spiral bundle; PBS, phosphate-buffered saline; RTPCR, reverse transcription polymerase chain reaction; SGN, spiral ganglion neurons; SNAP, soluble NSF attachment protein; SNAP-25, synaptosomalassociated protein of $25 \mathrm{kDa}$; SNARE, SNAP receptor; SSC, standard saline citrate; VAMP, vesicle-associated membrane protein.

\section{References}

Bennett, M.K., Calakos, N. \& Scheller, R.H. (1992) Syntaxin: a synaptic protein implicated in the docking of synaptic vesicles at presynaptic active zone. Science, 257, 255-259.

Bennett, M.K., Garcia-Arrarás, J.E., Elferink, L.A., Peterson, K., Fleming, A.M., Hazuka, C.D. \& Scheller, R.H. (1993) The syntaxin family of vesicular transport receptors. Cell, 74, 863-873.

Berglund, A.M. \& Ryugo, D.K. (1987) Hair cell innervation by spiral ganglion neurons in the mouse. J. Comp. Neurol., 255, 560-570.

Bezprozvanny, I., Scheller, R.H. \& Tsien, R.W. (1995) Functional impact of syntaxin on gating of N-Type and Q-type calcium channels. Nature, 37, 623-626.

Bobbin, R.P., Ceasar, G. \& Fallon, M. (1991) Changing cation levels $\left(\mathrm{Mg}^{2+}\right.$, $\mathrm{Ca}^{2+}, \mathrm{Na}^{+}$) alters the release of glutamate, GABA and other substances from guinea pig cochlea. Hear. Res., 54, 135-144.

Bock, J.B., Lin, R.C. \& Scheller, R.H. (1996) A new syntaxin family member implicated in targeting of intracellular transport vesicles. J. Biol. Chem., 271, 17961-17965.

Bock, J.B. \& Scheller, R.H. (1997) Protein transport. A fusion of new ideas. Nature, 387, 133-135.

Brandstätter, J., Wassle, H., Betz, H. \& Morgans, C.W. (1996) The plasma membrane protein SNAP-25, but not syntaxin, is present at photoreceptor and bipolar cell synapses in the rat retina. Eur. J. Neurosci., 8, 823-828.

Calakos, N. \& Scheller, R.H. (1994) Vesicle-associated membrane protein and synaptophysin are associated on the synaptic vesicle. J. Biol. Chem., 296, 24534-24537.

Chapman, E.R., Hanson, P.I., An, S. \& Jahn, R. (1995) $\mathrm{Ca}^{2+}$ regulates the interaction between synaptotagmin and syntaxin 1. J. Biol. Chem., 270, 23667-23671.

Craxton, M. \& Goedert, M. (1995) Synaptotagmin V: a novel synaptotagmin isoform expressed in rat brain. FEBS Lett., 361, 196-200.

Daly, C. \& Zip, E.B. (1997) Postranscriptional regulation of synaptic vesicle protein expression and developmental control of synaptic vesicle formation. J. Neurosci., 17, 2365-2375.

Edelmann, L., Hanson, P., Chapman, E.R. \& Jahn, R. (1995) Synaptobrevin binding to synaptophysin: a potential mechanism for controlling the exocytosis fusion machine. EMBO J., 14, 224-231.

Elferink, L.A., Trimble, W.S. \& Scheller, R.H. (1989) Two vesicle-associated membrane protein genes are differentially expressed in the rat central nervous system. J. Biol. Chem., 264, 11061-11064.

Elgoyhen, A.B., Johnson, D.S., Boulter, J., Vetter, D.W. \& Heinemann, S. (1994) $\alpha 9$ : an acetylcholine receptor with novel pharmacological properties expressed in rat cochlear hair cells. Cell, 79, 705-715.

Fuchs, P.A., Evans, M.G. \& Murrow, B.W. (1990) Calcium currents in hair cells isolated from the cochlea of the chick. J. Physiol. (Lond.), 429, 553-568.

Galli, T., McPherson, P.S. \& De Camilli, P. (1996) The V0 sector of the VATPase, synaptobrevin, and synaptophysin are associated on synaptic vesicles in a Triton X-100-resistant, freeze-thawing sensitive complex. J. Biol. Chem., 271, 2193-2198.

Garcia, E.P., Oherson, P.S., Chilcote, T.J., Take, K. \& De Camilli, P. (1995) nSec1A and B colocalized with syntaxin and SNAP-25 throughout the axon, but not in a stable complex. J. Cell Biol., 129, 105-120.

Geppert, M., Archer, B.T. \& Südhof, T.C. (1991) Synaptotagmin II. A novel differentially distributed form of synaptotagmin. J. Biol. Chem., 266, 13548-13552.

Gil-Loyzaga, P. \& Pujol, R. (1988) Synaptophysin in developing cochlea. Int. J. Devl. Neurosci., 6, 155-160. 
Gleisner, L., Flock, A. \& Wersall, J. (1973) The ultrastructure of the afferent synapse on hair cells in the frog labyrinth. Acta. Otolaryngol. (Stockh.), 76, 199-207.

Hata, Y. \& Südhof, T.C. (1995) A novel ubiquitous form of munc-18 interacts with multiple syntaxins use of the yeast two hybrid system to study interactions between proteins involved in membrane traffic. J. Biol. Chem., 270, 13022-31028.

Hudspeth, A.J. \& Issa, N.P. (1996) Confocal-microscopic visualization of membrane addition during synaptic exocytosis at presynaptic active zones of hair cells. Cold Spring Harb. Symp..Quant. Biol., 55, 547-561.

Issa, N. \& Hudspeth, A.J. (1996) Characterization of fluo-3 labeling of dense body at the hair cell's presynaptic active zone. J. Neurocytol., 25, 257-266.

Jahn R. \& Südhof, T.C. (1994) Synaptic vesicles and exocytosis. Annu. Rev. Neurosci., 17, 219-246.

Jahn. R., Schiebler, W., Ouimet, C. \& Greengard, P. (1985) A 38,000-dalton membrane protein (p38) present in synaptic vesicles. Proc. Natl Acad. Sci. USA, 82, 4137-4141.

Jenisson, G.L., Bobbin, R.P. \& Thalmann, R. (1985) Potassium-induced release of endogenous amino acids in the guinea pig cochlea. J. Neurochem., 44, 1845-1853.

Juusola, M., French, A.S., Uusitalo, R.O. \& Weckstrom, M. (1996) Information processing by graded-potential transmission through tonically active synapses. Trends Neurosci., 19, 292-297.

Kee, Y., Lin, R.C., Hsu, S.C. \& Scheller, R.H. (1995) Distinct domains of syntaxin are required for synaptic vesicle fusion complex formation and dissociation. Neuron, 14, 991-998.

Kee, Y. \& Scheller, R.H. (1996) Localization of synaptotagmin-binding domain on syntaxin. J. Neurosci., 16, 1975-81.

Laemmli, U.K. (1970) Cleavage of structural proteins during the assembly of the head of bacteriophage T4. Nature, 227, 680-685.

Leube, R.E., Kaiser, P., Seiter, A., Zimbelmann, R., Franke, W.W., Rehm, H., Knaus, P., Prior, P., Betz, H., Reinke, H., Beyreuther, K. \& Wiedenmann, B. (1987) Synaptophysin: molecular organization and mRNA expression as determined from cloned cDNA. EMBO J., 6, 3261-3268

Li, C., Ullrich, B., Zhang, J.Z., Anderson, R.G., Brose, N. \& Südhof, T.C. (1995) $\mathrm{Ca}^{2+}$-dependent and -independent activities of neural and non-neural synaptotagmins. Nature, 375, 594-599.

Matsubara, A., Laake, J.H., Davanger, S., Usami, S.-I. \& Ottersen, O.P. (1996) Organization of AMPA receptor subunits at a glutamate synapse: a quantitative immunogold analysis of hair cell synapses in the rat organ of Corti. J. Neurosci., 16, 4457-4467.

McMahon, H.T. \& Südhof, T.C. (1995) Synaptic core complex of synaptobrevin, syntaxin, and SNAP-25 forms high affinity alpha-SNAP binding site. J. Biol. Chem., 270, 2213-2217.

Mizuta, M., Inagaki, N., Nemoto, Y., Matsukura, S., Takahashi, M. \& Seino, S. (1994) Synaptotagmin III, a novel isoform of rat synaptotagmin expressed in endocrine and neuronal cells. J. Biol. Chem., 264, 11675-11678.

Morgans, C.W., Brandstätter, J.H., Kellerman, J., Betz, H. \& Wassle, H. (1996) A SNARE complex containing syntaxin 3 is present in ribbon synapses of the retina. J. Neurosci., 16, 6713-6721.

Oyler, G.A., Higgins, G.A., Hart, R.A., Battenberg, E., Billingsley, M., Bloom, F.E. \& Wilson, M.C. (1989) The identification of a novel synaptosomalassociated protein, SNAP-25, differentially expressed by neuronal subpopulations. J. Cell Biol., 109, 3039-3052.

Park, H.J., Niedzielski, A.S. \& Wenthold, R.J. (1997) Expression of the nicotinic acetylcholine receptor subunit, alpha9, in the guinea pig cochlea. Hear. Res., 112, 95-105.

Parson, T.D., Lenzi, D., Almers, W. \& Roberts, W.M. (1994) Calciumtriggered exocytosis and endocytosis in an isolated presynaptic hair cell: capacitance measurement in saccular hair cells. Neuron, 13, 875-883.

Perin, M.S., Brose, N., Jahn, R. \& Südhof, T.C. (1991) Domain structure of synaptotagmin (p65) [published erratum appears in J. Biol. Chem. 1991, 266, 10018]. J. Biol. Chem., 266, 623-629.

Pevsner, J. (1995) The role of Sec1p-related proteins in vesicle trafficking in nerve terminal. J. Neurosci. Res., 45, 89-95.

Pevsner, J., Hsu, S., Braun, J.E.A., Calakos, N., Ting, A.E., Bennett, M.K. \& Scheller, R.H. (1994) Specificity of and regulation of a synaptic vesicle docking complex. Neuron, 13, 353-361.

Rao-Mirotznik, R., Harkins, A.B., Buchsbaum, G. \& Sterling, P. (1995) Mammalian rod terminal: architecture of a binary synapse. Neuron, 14, 561-569.

Rieke, F. \& Schwartz, E.A. (1994) A cGMP-gated current can control exocytosis at cone synapses. Neuron, 13, 863-874.

Rossetto, O., Gorza, L., Schiavo, G., Schiavo, N., Scheller, R.H. \& FerroNovick, C. (1996) Vamp/synaptobrevin isoforms 1 and 2 are widely and differentially expressed in nonneuronal tissues. J. Cell Biol., 132, 167-179.

Safieddine, S. \& Wenthold, R.J. (1997) The glutamate receptor subunit delta1 is highly expressed in hair cells of the auditory and vestibular systems. J. Neurosci., 17, 7523-7531.

Scheller, R.H. (1995) Membrane trafficking in the presynaptic nerve terminal. Neuron, 14, 893-897.

Schiavo, G., Stenbeck, G., Rothman, J.E. \& Söllner, T.H. (1997) Binding of the synaptic vesicle v-SNARE, synaptotagmin, to the plasma membrane tSNARE, SNAP-25, can explain docked vesicles at neurotoxin-treated synapses. Proc. Natl Acad. Sci. USA, 94, 997-1001.

Shen, Z.-H., Retting, J., Takahashi, M. \& Catterall, W.A. (1994) Identification if syntaxin-binding site on N-Type calcium channels. Neuron, 13, 1303-1313.

Söllner, T., Bennett, M.K., Whiteheart, S.W., Scheller, R.H. \& Rothman, J.E. (1993a) A protein assembly-disassembly pathway in vitro that may correspond to sequential steps of synaptic vesicle docking, activation, and fusion. Cell, 75, 409-418.

Söllner, T., Whiteheart, S.W., Brunner, M., Erdjument-Bromage, H., Geromanos, S., Tempst, P. \& Rothman, J.E. (1993b) SNAP receptor implicated in vesicle targeting and fusion. Nature, 362, 318-324.

Spoendlin, H. (1972) Innervation densities of the cochlea [Innervation pattern as basis for cochlear function]. Acta. Otolaryngol. (Stockh.), 73, 235-248.

Su, Z.L., Jiang, S.C., Gu, R. \& Yang, W.P. (1995) Two types of calcium channels in bullfrog saccular hair cells. Hear. Res., 87, 62-68.

Südhof, T.C. (1995) The synaptic vesicle cycle: a cascade of protein-protein interactions. Nature, 375, 645-653.

Südhof, T.C., Czernik, A.J., Kao, H.T., Takei, K., Johnston, P.A., Horiuchi, A., Kanazir, S.D., Wagner, M.A., Perin, M.S., De Camilli, P. \& Greengard, P. (1989) Synapsins: mosaics of shared and individual domains in a family of synaptic vesicles. Phosphoproteins Sci., 245, 1474-1480.

Südhof, T.C. \& Rizo, J. (1996) Synaptotagmins: C2-domain proteins that regulate membrane traffic. Neuron, 17, 379-88.

Towbin, H., Staehelin, T. \& Gordon, J. (1979) Electrophoretic transfer of proteins from polyacrylamide gels to nitrocellulose sheets: procedure and some applications. Proc. Natl Acad. Sci. USA, 76, 4350-4354.

Trimble, W.S., Gray, T.S., Elferink, L.A., Wilson, M.C. \& Scheller, R.H. (1990) Distinct patterns of expression of two VAMP genes within the rat brain. J. Neurosci., 10, 1380-1387.

Ullrich, B., Li., Zhang, J.Z., McMahon, H., Anderson, R.G., Geppert, M. \& Südhof, T.C. (1994) Functional properties of multiple synaptotagmins in brain. Neuron, 13, 1281-1291.

Ullrich, B. \& Südhof, T.C. (1994) Distribution of synaptic markers in the retina: implications for synaptic vesicle traffic in ribbon synapses. J. Physiol., 88, 249-257.

Warr, W.B., Boche, J.B. \& Neely, S.T. (1997) Efferent innervation of the inner hair cell region: origins and terminations of two lateral olivocochlear systems. Hear. Res., 108, 89-111.

Washbourne, P., Schiavo, G. \& Montecucco, C. (1995) Vesicle-associated membrane protein-2 (synaptobrevin-2) forms a complex with synaptophysin. Biochem. J., 305, 721-724. 